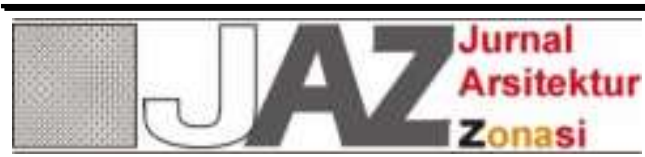

http://ejournal.upi.edu/index.php/jaz/ - e-mail: jurnal.zonasi@gmail.com dan jurnal_zonasi@upi.edu

\title{
STRATEGI KONSERVASI GUNA MEMPERTAHANKAN IDENTITAS ARSITEKTUR PURA SITUS DI DESA SIBANG (PENGURANGAN RESIKO SOSIAL, EKONOMI, DAN ARSITEKTURAL)
}

\author{
Article History: \\ First draft received: \\ 21 Januari 2019 \\ Revised: \\ 29 Januari 2019 \\ Accepted: \\ 4 Februari 2019 \\ Final proof received: \\ Print: \\ 10 Februari 2019

\section{Online} \\ 11 Februari 2019
}

\author{
Ni Putu Ratih Pradnyaswari Anasta Putri ${ }^{1}$ \\ I Putu Adi Widiantara ${ }^{2}$ \\ 1,2 Program Studi Teknik Arsitektur, Fakultas Teknik, Universitas Warmadewa, Denpasar, \\ Indonesia \\ Jalan Terompong No. 24 Tanjung Bungkak, Denpasar, Bali \\ Email : pradnyaswari.anasta@gmail.com
}

Abstract: Pura is one of Balinese architectural works that serves as a place of worship for Hindus. Pura as one of the local wisdom of the Balinese people is often associated with the identity of a region and cultural heritage. Pura is considered as one of the real proofs of the history of history from the past until now. The rolling of time and time, and the absence of adequate historical documentation regarding temples in Bali caused changes and developments that often did not match the standard. Many factors can be said to be the cause of changes or developments in a temple, including: (1) lack of documentation; (2) understanding of local people who are still minimal in the process of building a temple; (3) the absence of rules, awig-awig, or guidelines regarding the process of building a temple; (4) the people's desire to carry out practical and inexpensive temple renovation processes; and (5) people's insensitivity to the identity of their territory. Sites that have historical value are instead replaced with new or current models that are not necessarily based on original literature from previous ancestral orders. Seeing this phenomenon, researchers believe that there needs to be a preservation effort, namely a conservation strategy so that changes and developments can be overcome and controlled according to their portion. This research was carried out in an exploratory manner with qualitative data analysis, which explores data in depth through in-depth interviews.

Keywords : Pura, Site, Conservation, Identity

Abstrak: Pura merupakan salah satu karya arsitektur Bali yang berfungsi sebagai tempat ibadah bagi umat Hindu. Pura sebagai salah satu kearifan lokal masyarakat Bali seringkali dikaitkan dengan identitas suatu wilayah dan warisan budaya. Pura dianggap sebagai salah satu bukti nyata perjalanan sejarah dari masa lampau hingga sekarang. Bergulirnya waktu dan jaman, serta tidak adanya dokumentasi sejarah yang memadai mengenai pura-pura di Bali menyebabkan terjadinya perubahan dan perkembangan yang seringkali tidak sesuai pakemnya. Banyak faktor yang dapat dikatakan sebagai penyebab dalam perubahan ataupun perkembangan sebuah pura, antara lain : (1) tidak adanya dokumentasi; (2) pemahaman masyarakat setempat yang masih minim terhadap proses pembangunan sebuah pura; (3) tidak adanya aturan, awig-awig, ataupun guidelines mengenai proses pembangunan sebuah pura; (4) keinginan masyarakat untuk melakukan proses renovasi pura dengan praktis dan murah; dan (5) ketidakpekaan masyarakat akan identitas wilayahnya. Situs-situs yang memiliki nilai historis malah diganti dengan model kebaruan atau kekinian yang belum tentu berdasarkan sastra asli dari tatanan leluhur sebelumnya. Melihat fenomena tersebut, peneliti meyakini perlu adanya sebuah upaya pelestarian yaitu strategi konservasi sehingga perubahan dan perkembangan dapat diatasi dan dikendalikan sesuai dengan porsinya. Penelitian ini dilakukan secara eksploratif dengan analisis data kualitatif, dimana menggali data sedalam-dalamnya melalui wawancara mendalam (in depth interview).

Kata Kunci: Pura, Situs, Konservasi, Identitas 


\section{Pendahuluan}

Arsitektur sebagai wujud warisan budaya dapat dilihat dari dua faktor utama pembentuknya, yaitu : faktor fisik (tangible) dan non fisik (intangible). Faktor fisik (tangible) dapat ditentukan dalam bentuk yang dapat terlihat secara visual ataupun kasat mata seperti wujud, dimensi, proporsi, struktur, material, hingga elemen dekorasi. Faktor non fisik (intangible) dapat terlihat dari nilai-nilai filosofis, norma, sejarah, konsep, dan adat istiadat yang terkandung di dalamnya. Kedua faktor utama tersebut dirangkaikan dengan nilai-nilai arsitektur sehingga menghasilkan sebuah karya yang dapat dijadikan bukti jejak sejarah ataupun sebagai ciri sebuah identitas lokal suatu wilayah.

Pura merupakan salah satu karya arsitektur Bali yang berfungsi sebagai tempat ibadah dan pelaksanaan yadnya bagi umat Hindu. Pembangunan sebuah pura tidak akan lepas dari konsep kearifan lokal masyarakat Bali. Pura sebagai salah satu kearifan lokal masyarakat Bali seringkali dikaitkan dengan identitas suatu wilayah dan warisan budaya. Pura dianggap sebagai salah satu bukti nyata perjalanan sejarah dari masa lampau hingga sekarang. Bergulirnya waktu dan jaman, serta tidak adanya dokumentasi sejarah yang memadai mengenai pura-pura di Bali menyebabkan terjadinya perubahan dan perkembangan yang seringkali tidak sesuai pakemnya.

Tidak sedikit pura-pura yang ada di Bali, telah mengalami perubahan baik itu dari segi fisik maupun non-fisik, sehingga menjadikan masyarakat sekarang kurang mengetahui nilai dan makna historis dari sebuah situs pura tersebut. Sesungguhnya banyak faktor yang dapat dikatakan sebagai penyebab dalam perubahan ataupun perkembangan sebuah pura, antara lain : (1) tidak adanya dokumentasi yang mumpuni mengenai sejarah ataupun proses pembangunan sebuah pura; (2) pemahaman masyarakat setempat yang masih minim terhadap proses pembangunan sebuah pura (missal : pemahaman mengenai material setempat, tata cara membangun); (3) tidak adanya aturan, awig-awig, ataupun guidelines mengenai proses pembangunan sebuah pura; (4) keinginan masyarakat untuk melakukan proses renovasi pura dengan praktis dan murah sehingga seringkali melanggar beberapa aturan yang telah dibuat; dan (5) ketidakpekaan masyarakat akan identitas wilayahnya.

Perubahan dan perkembangan pura yang terjadi secara besar-besaran saat ini juga diperparah dengan turunnya dana Bansos (bantuan sosial) dari pemerintah yang seringkali tidak sesuai dengan tempatnya, sehingga akibatnya banyak pura-pura yang dibongkar secara "paksa" yang tanpa sadar merusak situs-situs yang memiliki tatanan nilai dan jejak leluhurnya sendiri. Ironisnya, situs-situs yang memiliki nilai historis malah diganti dengan model kebaruan atau kekinian yang belum tentu berdasarkan sastra asli dari tatanan leluhur sebelumnya.

Melihat fenomena tersebut, peneliti meyakini perlu adanya sebuah upaya pelestarian yaitu konservasi dengan beberapa macam tipe strategi dan pengelolaan sehingga perubahan dan perkembangan dapat diatas dan dikendalikan sesuai dengan porsinya. Pemilihan Desa Sibang sebagai lokasi penelitian didasarkan pada beberapa pertimbangan, antara lain : (1) lokasi Desa Sibang, cukup dekat dengan Denpasar sebagai ibukota propinsi, hanya saja Desa Sibang merupakan desa yang cukup asli dan belum terlalu tergerus modernitas; (2) Desa Sibang berada di dalam wilayah Kabupaten Badung, yang selama ini dianggap sebagai kabupaten yang mengeluarkan dana-dana bantuan sosial terbesar dalam proyek renovasi pura; (3) Desa Sibang memiliki beberapa pura-pura situs yang masih cukup asli dan disakralkan yang dapat dijadikan objek penelitian; dan (4) daerah yang masih asli membuat data atau informasi yang didapat lebih mudah dikarenakan masyarakat yang tinggal di sekitar objek penelitian sebagian besar merupakan penduduk asli sehingga cukup kooperatif dalam memberikan informasi.

\section{Metode Penelitian}

Penelitian ini dilakukan secara eksploratif dengan analisis data kualitatif, dimana menggali data sedalam-dalamnya melalui wawancara mendalam (in depth interview). Penelitian ini merupakan penelitian kualitatif yang sangat erat kaitannya dengan faktor-faktor kontekstual yang khas (unik), sehingga setiap konteks itu ditangani dari segi konteksnya sendiri. Untuk penelitian ini, objek kajiannya adalah Pura-Pura Situs yang terdapat di Desa Sibang dengan mengkaji karakteristik dan perkembangan arsitektur pada purapura situs di Desa Sibang berdasarkan waktu sekarang merunut kebelakang hingga data jenuh serta menjelaskan faktor-faktor penyebab perkembangannya. Data ini nantinya akan dikaitkan dengan teori konservasi sehingga nantinya akan disimpulkan strategi konservasi yang tepat dilakukan terhadap pura-pura situs di Desa Sibang.

Pemilihan objek kajian dalam penelitian ini didasarkan pada beberapa hal, antara lain : (1) pura merupakan pura situs atau memiliki cerita sejarah; (2) arsitektur pura masih cukup asli (tidak banyak berubah dengan presentase 30-40\% perubahan); (3) pura memiliki tingkat keaslian pura yang masih cukup otentik, 
penggunaan material yang masih cukup sesuai dengan kondisi setempat. Adapun sebaran objek penelitian dijelaskan dalam gambar 1 .

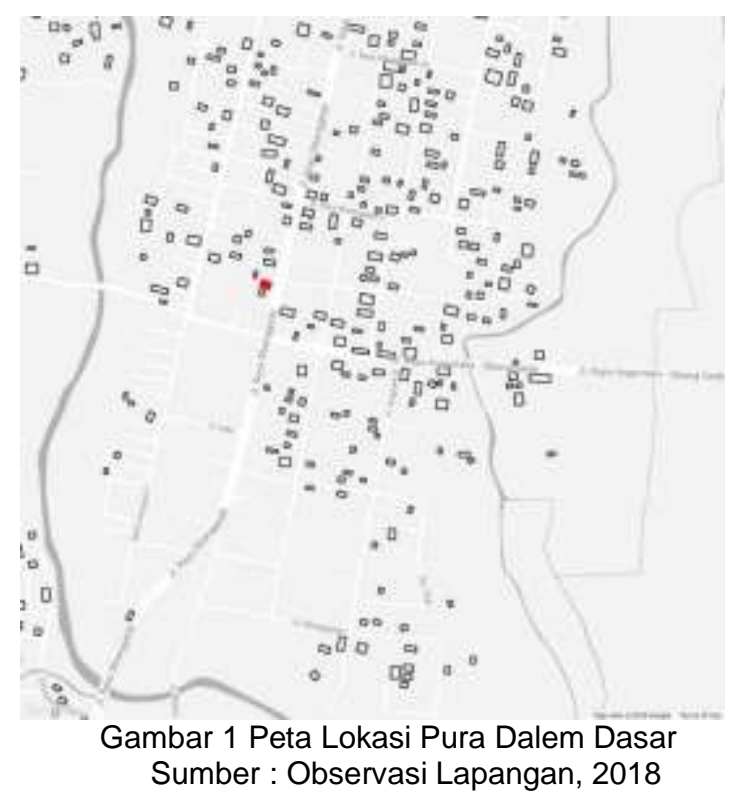

\section{Hasil dan Pembahasan}

Pura Dalem Dasar diyakini berawal dari Kerajaan Mengwi yang berkuasa di Badung. "Zaman dulu pura tersebut merupakan paica (hadiah) dari Raja Klungkung Ida Dewa Agung Made kepada Kerajaan Mengwi. Dikarenakan di sana tidak ada tempat, maka dipilihlah daerah Desa Sibang (wawancara dengan Pemangku Nyoman Gunarta, Juli 2018).

\subsection{Fungsi Pura Dalem Dasar Ditinjau dari Aspek Religius}

Fungsi Pura Dalem Dasar secara religius sebagai tempat persembahyangan umat Hindu yang melakukan pemujaan terhadap Ida Sang Hyang Widhi dan segala manifestasinya serta tempat untuk mensucikan diri secara niskala. Pura Dalem Dasar tidak hanya mempunyai fungsi religius keagamaan saja, namun juga memiliki fungsi religius sesuai dengan kepercayaan masyarakat setempat. Hal ini dapat dilihat dengan keberadaan pelinggih dengan fungsinya tersendiri, misalnya saja : (1) Pelinggih dengan wujud Patih yang memiliki fungsi sebagai pelinggih pemujaan untuk memohon pengobatan dan memohon keturunan, khususnya keturunan laki-laki,

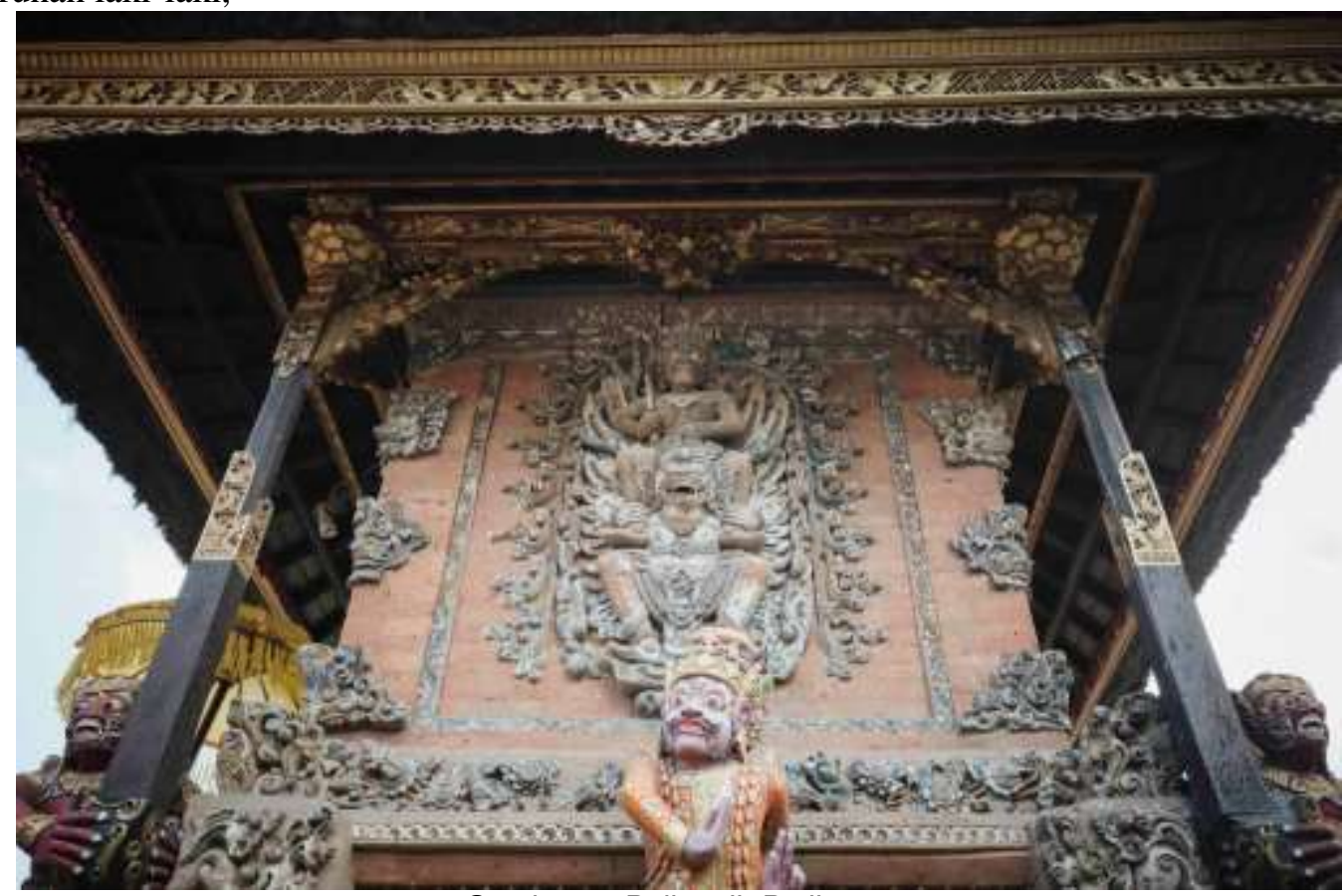

Gambar 2. Pelinggih Patih

Sumber : Dokumentasi Pribadi, Agustus 2018 
atau (2) Pelinggih Hyang Ibu, merupakan stana leluhur sebagai Dewa Hyang atau batara-batari. Pada pelinggih Hyang Ibu ini bertujuan untuk memuja betara-betari dengan soroh atau klan Pasek.

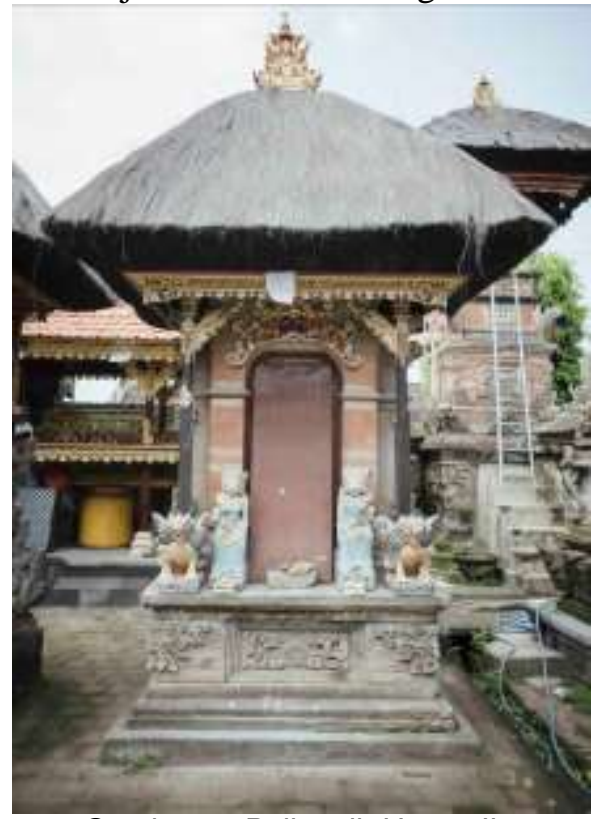

Gambar 3. Pelinggih Hyang Ibu

Sumber : Dokumentasi Pribadi, Agustus 2018

Keberadaan pelinggih-pelinggih tersebut menjadikan pemedek atau orang-orang yang bersembahyang di Pura Dalem Dasar tidak hanya warga Desa Sibang, tetapi juga beberapa warga di daerah Petang, Abiansemal, dan Darmasaba dengan total pengempng kurang lebih 12 kepala keluarga yang utamanya merupakan soroh atau klan Pasek. Pura Dalem Dasar juga memiliki fungsi sosial yang dapat dilihat dari interaksinya, dimana pemedek Pura Dalem dasar terbagi atas keluarga puri maupun masyarakat biasa. Bahkan, terdapat beberapa orang yang memohon kesembuhan atau memohon keturunan disini turut dalam kegiatan yadnya yang dilakukan di Pura Dalem Dasar.

\subsection{Fungsi Pura Dalem Dasar Ditinjau dari Aspek Sosial - Pendidikan}

Secara sosial di bidang pendidikan, Pura Dalem Dasar dapat dijadikan sumber belajar formal maupun non-formal dengan memanfaatkan potensi yang dimiliki Pura Dalem Dasar. Secara non-formal pendidikan dapat diperoleh melalu kegiatan ngayah di Pura baik itu gotong royong, membuat banten, tari-tarian, maupun bermain alat musik. Sedangkan secara formal terdapat beberapa ptensi yang dimiliki Pura Dalem Dasar, antara lain : (1) aspek historis melalui berdirinya pura maupun proses perkembangan dan perubahan pelinggih-pelinggih yang ada di Pura Dalem Dasar; (2) aspek peninggalan dimana terdapat beberapa peninggalan-peninggalan yang dapat dijadikan sumber belajar, antara lain : relief pada pelinggih atau tembok penyengker yang menceritakan kisah sesuai sastra, penggunaan material pada Pura Dalem Dasar yang masih asli sejak abad 18, sistem pengecatan pada pelinggih-pelinggih yang masih menggunakan teknik alami, serta sistem struktur pada gedong yang masih asli.
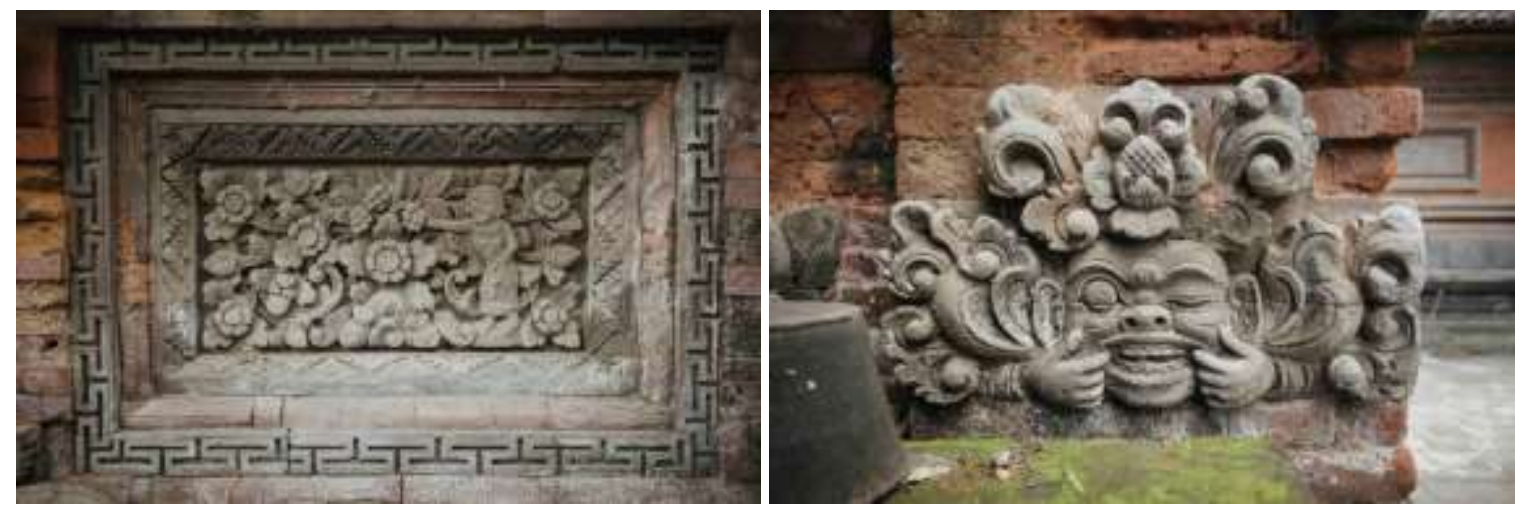

'Gambar 4. Ragam Hias yang terdapat di Pura Dalem Dasar Sumber : Dokumentasi Pribadi, Agustus 2018 


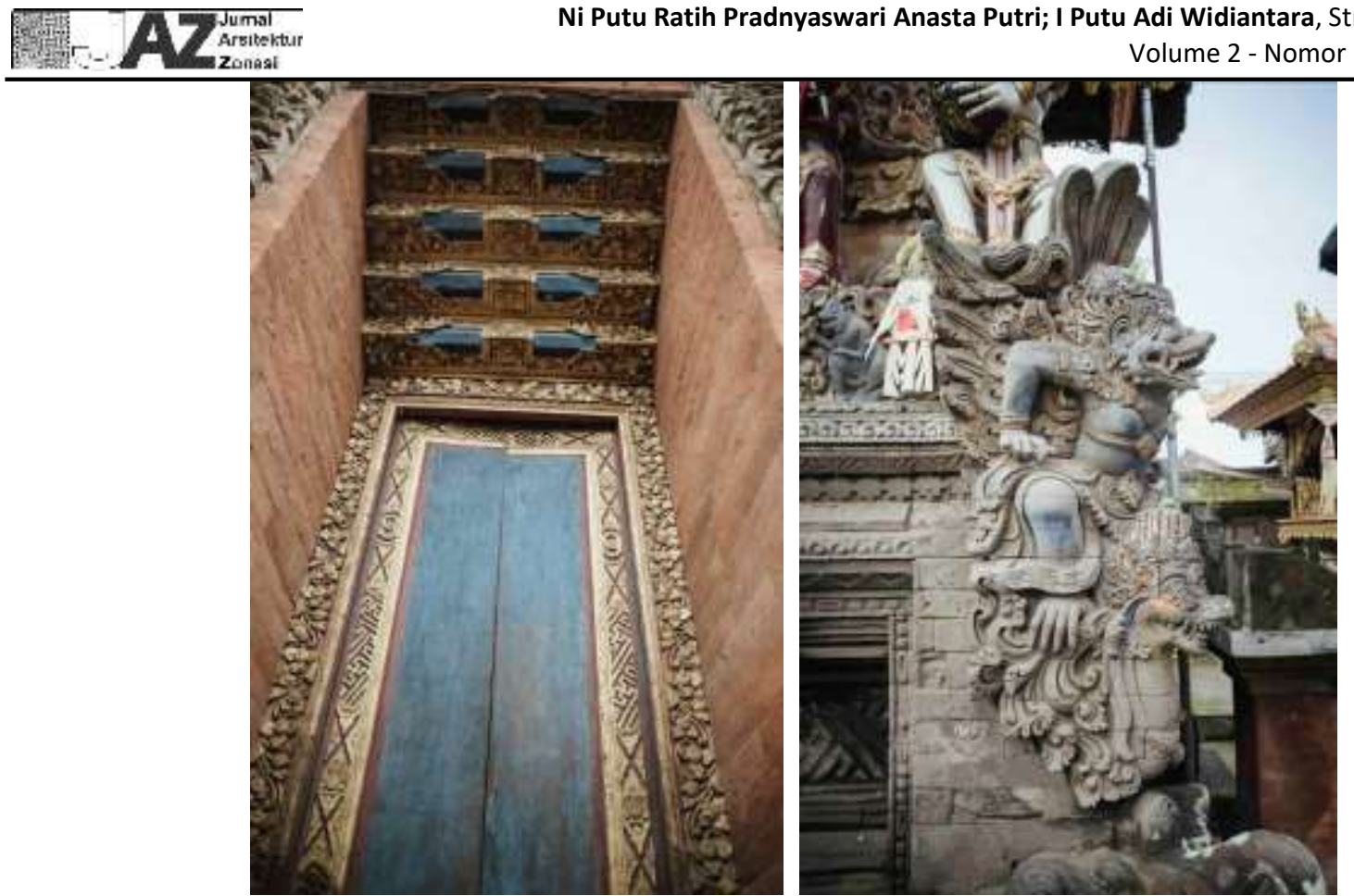

Gambar 5. (Kanan) Pewarnaan dengan warna emas \& biru menggunakan bahan kimia (Kiri) Pewarnaan dengan warna alami berbahan dasar permata Sumber : Dokumentasi Pribadi, Agustus 2018

\subsection{Fungsi Pura Dalem Dasar Ditinjau dari Aspek Arsitektural}

Secara arsitektural, Pura Dalem Dasar yang dijadikan objek kajian memiliki nilai warisan budaya yang bersifat arsitektural yang dimana apabila hilang akibat bencana yang disengaja ataupun tidak maka nilai tersebut akan sulit diteruskan ke generasi selanjutnya karena tidak ada dokumentasi yang mempuni. Secara nilai arsitektural, misalnya saja pada struktur halaman atau mandala dari Pura Dalem Dasar. Pada dasarnya struktur pembagian halaman pura pada Pura Dalem Dasar sama seperti pura pada umumnya di Bali. Pura Dalem Dasar merupakan pura yang menggunakan konsep $d$ wi mandala yaitu pembagian pura yang terbagi menjadi dua bagian yaitu Utama Mandala (Jeroan) dan Nista Mandala (Jaba Sisi). Konsep Dwi Mandala yang melambangkan alam atas (urdhah) dan alam bawah (adhah).

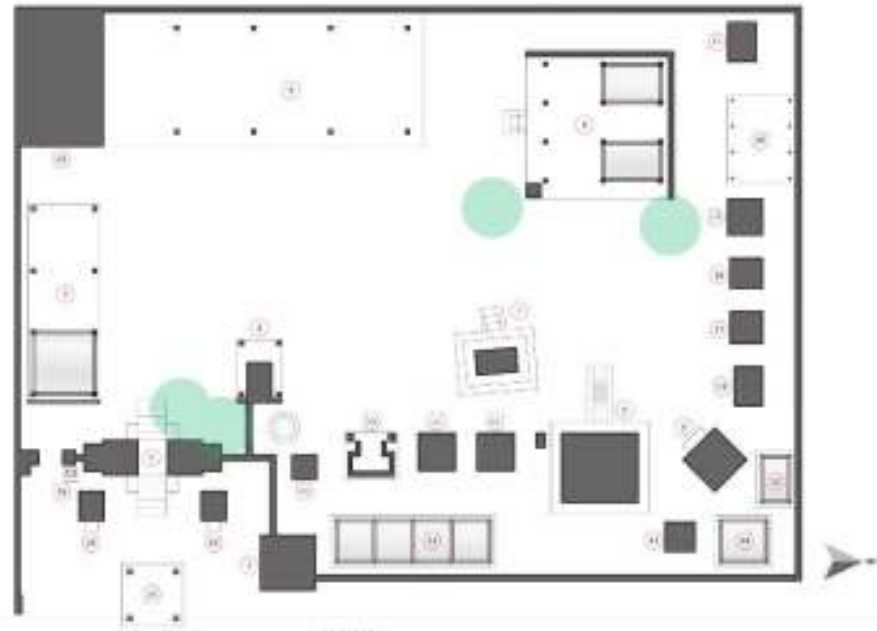

Gambar 6. Strukur Mandala pada Pura Dalem Dasar Sumber : Dokumentasi Pribadi, Agustus 2018

Tidak hanya pembagian mandala yang sudah sesuai dengan konsep Mandala, perletakkan bangunan di Pura Dalem Dasar pada awalnya telah sesuai dengan sikut yang dimiliki yang telah diatur oleh asta kosala-kosali bagi pura. Hanya saja terdapat beberapa perubahan ukutan sikut yang diakibatkan oleh renovasi beberapa pelinggih 
mengakibatkan beberapa jarak antar pelinggih tidak sesuai dengan proporsinya (akan dibahas pada sub-bab selanjutnya). Pembagian Mandala dan asta kosala-kosali telah diyakini oleh masyarakat di Bali khususnya umat Hindu sebagai filosofi yang dapat memberikan keharmonisan dan keselamatan. Oleh karena itu, pelestarian struktur pada pura sangat penting .

Selain stuktur mandala yang menjadi nilai warisan budaya, terdapat struktur pada masing-masing bangunan yang juga merupakan nilai penting dalam nilai struktur sebagai nilai warisan budaya, antara lain kori agung, bale kulkul, dan gedong yang dianggap sebagai warisan budaya yang sangat penting di Pura Dalem Dasar. Struktur atap atau kepala pada bangunan pura di Pura Dalem Dasar sebagian besar mengunakan kayu dan ijuk sebagai penutup atap (kecuali bale gede menggunakan ilalang yang kemudian diganti menggunakan penutup atap genteng sejak tahun 1982). Tidak ada perubahan yang signifikan pada struktur atap atau kepala, dikarenakan pura merupakan bangunan suci sehingga dianggap sakral, hanya saja dilakukan pemeliharaan terhadap struktur atap yang menggunakan kayu dan ijuk kurang lebih setiap 20 tahun sekali.

Stuktur badan pada pelinggih di Pura Dalem Dasar menggunakan tiang-tiang saka yang terbuat dari material kayu, sedangkan ruang-ruang pada pelinggih dan dinding menggunakan batu bata merah dan paras sebagai ciri khas bangunan pura di Kabupaten Badung. Selain itu terdapat keunikan struktur badan pada bangunan gedong yang dimana tiang-tiang saka tergantung pada atap sehingga saka atau tiang tidak menanggung beban atau dianggap sebagai hiasan saja. Struktur kayu atau tiang-tiang saka di Pura Dalem Dasar umumnya sudah banyak yang digantikan dengan kayu baru akibat kondisi yang sudah lapuk (kecuali gedong) atau tuntutan dari pengemong pura, hanya saja perubahan yang dilakukan tersebut tidak merubah posisi ataupun sikut asli dari pelinggih-pelinggih tersebut. Secara struktur kaki, sesuai dengan jenis bangunannya. Bangunan-bangunan pelinggih di Pura Dalem Dasar menggunakan pondasi jongkok asu dan pondasi menerus sebagai sistem struktur pada kaki bangunannya. Ketiga sistem struktur pada bangunan-bangunan di Pura Dalem Dasar baik struktur pada bagian kaki, kepala, dan badan masih tetap dipertahankan meskipun terdapat beberapa perkembangan sebagai tuntutan zaman.

\subsection{Fungsi Pura Dalem Dasar Ditinjau dari Aspek Sosial, Ekonomi, dan Arsitektural}

Ditinjau dari ketiga kasus yang diangkat, baik secara sosial, ekonomi, maupun arsitektural sesungguhnya tidak ada permasalahan yang mendasar dalam mempertahankan identitas pura situs ini, hanya saja kemajuan nilai ekonomi juga harus tetap diperhatikan karena seringkali menjadi penyebab yang "disengaja" perubahan sebuah pura situs. Seringkali pembongkaran pura situs yang diakibatkan sebuah nilai ekonomi tidak didasarkan pada penelitian mendalam terlebih dahulu, sehingga seringkali nilainya ikut berubah seiring dengan perubahan bentuknya secara arsitektural.

Perubahan dan perkembangan yang "disengaja" ini juga seringkali didasrkan pada faktor sosial, yang diakibatkan keinginan "gengsi" seseorang atau sekelompok yang secara sengaja melakukan pembongkaran atau renovasi sebuah pura situs tanpa melakukan penelitian mendalam mengenai nilai sosial, nilai bentuk, dan nilai kesakrakalan sebuah pura situs.

Perkembangan dan perubahan pura situs khususnya yang disengaja, sebaiknya tetap memperhatikan konteks setempat dan menyesuaikan dengan kebaharuan yang ada. Misalnya saja, pada kasus ketidaktersediaan bahan. Seringkali ditemukan kasus perubahan material diakibatkan ketidaktersediaan bahan asli, sehingga ada baiknya dilakukan studi kasus mendalam terlebih dahulu untuk menyesuaikan bahan yang digunakan sesuai dengan aturan setempat (awig-awig) dan konteks material setempat.

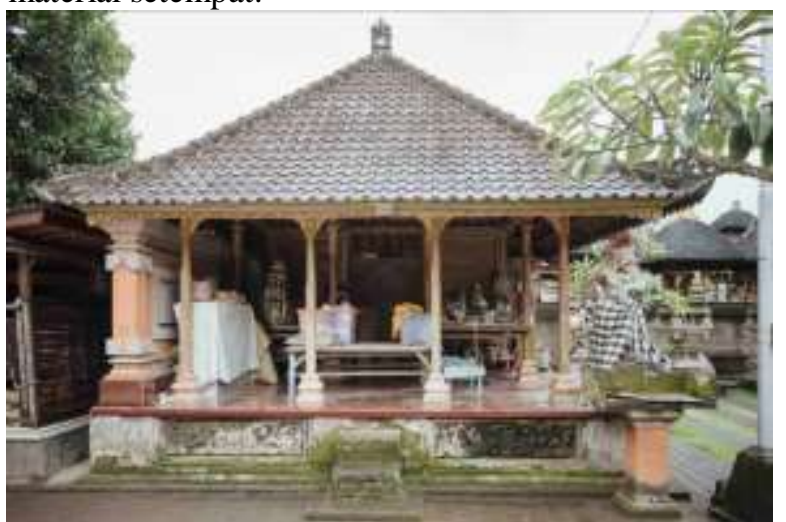

Gambar 7. Bale Gede yang dimana atapnya telah berubah karena alasan ketidaktersediaan bahan asli lagi. Meskipun mengalami perubahan, nilainya tetap sama.

Sumber : Dokumentasi Pribadi, Agustus 2018

\section{Kesimpulan}

Simpulan penelitian ini memuat dua pokok hasil penelitian yang membahas mengenai kondisi bentuk fisik, ruang, serta fungsi yang mendasari perubahan sehingga dibutuhkan strategi konservasi dalam mempertahankan pura situs tersebut.

1. Perkembangan yang terjadi belum dapat dikatakan memberikan intervensi negative pada pura situs, meskipun nilai keruangan pada bangunan mengalami sedikit perubahan namun nilai keruangan secara niskala melalui keberadaan masih dipertahankan dengan sangat baik. Hal ini dikarenakan bangunan- 
bangunan yang memiliki signifikasi budaya dan agama, umumnya fungsinya masih tetap bertahan dan tetap terpelihara, bahkan seringkali keberadaan fisiknya lebih terpelihara dengan baik. Meskipun terjadi perkembangan pada masing-masing bangunan, berdasarkan keberadaan fisik saat ini dapat dinyatakan bahwa pola mandala dan keruangan pura masih dapat dipertahankan dan dilestarikan.

2. Perkembangan arsitektur pada pura situs tentunya dipengaruhi oleh beberapa faktor baik secara internal maupun eksternal. Faktor perubahan ekonomi, pendidikan, dan aktivitas sosial masyarakatnya merupakan faktor utama yang menyebabkan terjadinya perkembangan pada pura situs di Desa Sibang.

3. Perkembangan pura situs yang didorong oleh faktor-faktor tersebut sesungguhnya bernilai positif, dan belum dapat dikatakan memberikan intervensi negatif, hal ini terlihat dari pura yang masih berdiri ajeg dan tetap eksis sebagai warisan budaya dan warisan arsitektur tradisional Bali.

4. Meskipun belum memberikan intervensi negatif dibutuhkan strategi konservasi dalam mempertahankan nilainya, antara lain berupa : (1) dokumentasi yang mempuni; (2) addisi; dan (3) restorasi.

\section{Ucapan Terima Kasih}

Terima kasih kami ucapkan kepada Redaksi Jurnal Arsitektur Zonasi yang telah memberikan kami kesempatan untuk menerbitkan tulisan kami. Terima kasih juga kami sampaikan kepada Panitia Seminar Nasional Konsep dan Implementasi (KonsepSi) \#3, Fakultas Teknik Universitas Warmadewa yang telah menjadi jembatan untuk menghubungkan kami dengan tim redaksi Jurnal Arsitektur Zonasi.

\section{Refrensi}

Budihardjo, E. (1991). Architectural Conservation in Bali. Yogyakarta: Gadjah Mada University Press.

Nyoman Darta, I Gusti. (2013). Times, Rites, and Festivals in Bali. Inodnesia: BAB Publishing Indonesia

Nuryanti, Windu. (2009). The Role of Heritage Tourism in Community Planning and Development. Yogyakarta: Gadjah Mada University Press

Putri, Ni Putu Ratih Pradnyaswari Anasta Putri. (2016). Perkembangan Arsitektur pada Palebahan di Puri Agung Peliatan Ubud, Gianyar. Jogjakarta: Universitas Gadjah Mada.

Rahyuda, Irma. (2012). Wisata Puri sebagai Daya Tarik dan Tujuan Wisata Budaya di Bali, Denpasar : Tesis Kajia Pariwisata Udayana.

Runa, I. W. (2016). Konservasi Bangunan Bersejarah (Studi Kasus Bangunan Peribadatan di Pulau Bali). Undagi : Universitas Warmadewa

Salain, N. R. (2011). Pengelolaan Konservasi pada Puri Agung Ubud, Gianyar sebagai Obyek Wisata Budaya. Bali: Universitas Udayana.

Surina, I. W. (2014). Pura Puseh, Pura Desa Batuan dalam Perkembangan Kepariwisataan Bali di Batuan Kecamatan Sukawati Kabupaten Gianyar. Santiaji Pendidikan. Volume 4, Nomor 1, 1-11.

Sugiyono. (2008). Metode Penelitian Kuantitatif, Kualitatif, dan R\&D. Bandung: Alfabeta

Republik Indonesia. (2010). Undang-Undang RI Nomor 11 tahun 2010 tentang Cagar Budaya. Jakarta: Percetakkan Negara 